\title{
Novel Human NK Cell Line Carrying CAR Targeting EGFRvIII Induces Antitumor Effects in Glioblastoma Cells
}

\author{
TOSHIHARU MURAKAMI ${ }^{1 *}$, TSUTOMU NAKAZAWA ${ }^{1 *}$, ATSUSHI NATSUME ${ }^{2}$, FUMIHIKO NISHIMURA $^{1}$, \\ MITSUTOSHI NAKAMURA ${ }^{1}$, RYOSUKE MATSUDA $^{1}$, KOJI OMOTO $^{1}$, YOSHITAKA TANAKA ${ }^{1}$, \\ YOUICHI SHIDA ${ }^{1}$, YOUNG-SOO PARK ${ }^{1}$, YASUSHI MOTOYAMA ${ }^{1}$, ICHIRO NAKAGAWA $^{1}$, \\ SHUICHI YAMADA ${ }^{1}$, KENTARO TAMURA ${ }^{1}$, YASUHIRO TAKESHIMA ${ }^{1}$, \\ YOSHIAKI TAKAMURA ${ }^{1}$, TOSHIHIKO WAKABAYASHI $^{2}$ and HIROYUKI NAKASE ${ }^{1}$ \\ ${ }^{1}$ Department of Neurosurgery, Nara Medical University, Kashihara, Japan; \\ ${ }^{2}$ Department of Neurosurgery, Nagoya University, Graduate School of Medicine, Nagoya, Japan
}

\begin{abstract}
Background/Aim: Natural killer (NK) cells are considered potential antitumor effector cells. The aim of this study was to establish a novel type of a chimeric antigen receptor (CAR) NK cell line (CAR-KHYG-1) specific for epidermal growth factor receptor variant III (EGFRvIII)expressing tumors and investigate the anti-tumor activity of EGFRvIII-specific-CAR-KHYG-1 (EvCAR-KHYG-1). Materials and Methods: EvCAR-KHYG-1 was established by self-inactivated lentiviral-based transduction of the EvCAR gene and magnetic bead-based purification of EvCARexpressing NK cells. The anti-tumor effects of EvCARKHYG-1 were evaluated using growth inhibition and apoptosis detection assays in glioblastoma (GBM) cell lines (EGFRvIII-expressing and non-expressing U87MG). Results: The findings demonstrated that EvCAR-KHYG-1 inhibited GBM cell-growth via apoptosis in an EGFRvIII-expressing specific manner. Conclusion: This is the first study to establish a CAR NK cell line based on the human NK cell line KHYG-1. Therapy with EvCAR-KHYG-1 may be an effective treatment option for GBM patients.
\end{abstract}

Glioblastoma (GBM) is one of the most common and aggressive primary malignant brain tumors occurring in adults (1-3). Even after undergoing chemotherapy, radiation,

\footnotetext{
*These Authors contributed equally to this study.

Correspondence to: Fumihiko Nishimura, Department of Neurosurgery, Nara Medical University, 840 Shijo-cho Kashihara city, Nara, Japan. Tel: +81 744298866, Fax: +81 744290818, e-mail: fnishi@naramed-u.ac.jp

Key Words: Chimeric antigen receptor, natural killer cells, glioblastoma, epidermal growth factor receptor variant III.
}

and/or surgical resection, few patients survive more than 5 years (2-4). Thus, new therapeutic strategies are needed. Immune-based therapy for GBM is a promising alternative to conventional treatments, with the possible long-term benefit of generating a sustainable anti-tumor response, and the potential to target both localized and infiltrating tumor cells (4-11). Natural killer (NK) cells respond rapidly to transformed and stressed cells, and represent an important effector cell type for adoptive immunotherapy $(12,13)$. In addition to donor-derived primary NK cells, continuously expanding cytotoxic cell lines, such as NK-92, are under development for clinical applications $(14,15)$. Additionally, NK cells have advantages over T cells, as they express the Fc fragment of the IgG low affinity III receptor (FcyR III), which binds to the $\mathrm{Fc}$ fragment of antibodies to elicit antibody-dependent cell-mediated cytotoxicity. This specific feature of NK cells enables the combination of 2 targeted therapies that recognize different, or the same, tumorassociated antigens, namely chimeric antigen receptor (CAR)-expressing NK cells (CAR NK) and tumor-associated antigen-specific monoclonal antibodies. NK cells spontaneously kill tumor cells by recognizing diverse ligands via a variety of activating receptors, including natural cytotoxicity receptors.

CAR is an artificially modified fusion protein consisting of an extracellular antigen recognition domain fused to an intracellular signaling domain $(4,16)$, and redirects the specificity and function of $\mathrm{T}$ lymphocytes and other immune cells. The general premise for the use of CAR cells in cancer immunotherapy is the rapid generation of tumor-targeted $\mathrm{T}$ cells, thus bypassing the barriers and incremental kinetics of active immunization $(17,18)$.

CAR T cells (CAR T) have been effectively used for treatment of refractory chronic lymphocytic leukemia and acute lymphoblastic leukemia $(19,20)$. Specifically, CD19- 
targeting CAR T have been reported to result in complete response rates of $70 \%$ to $90 \%$ in patients with ALL (21). However, CAR T exhibit poor therapeutic efficacy when used to treat solid tumors (22-24).

Similar to CAR T, CAR NK have exhibited improved tumor-specific targeting and cytotoxicity against cancer cells in both in vitro and in vivo experiments $(25,26)$. Importantly, NK cells have many advantages as compared to $\mathrm{T}$ cells for use in CAR-targeted immunotherapy $(27,28)$. For example, allogeneic NK cells can be used as effector cells, since they are not responsible for graft-versus-host disease (GVHD) because they do not require HLA matching. Furthermore, CAR NK may be safer than CAR T, as they usually do not induce cytokine storms, which are seen with CAR T $(29,30)$. Additionally, NK cells can be generated from a variety of sources, such as peripheral blood, umbilical cord blood, human embryonic stem cells, induced pluripotent stem cells, and even NK cell lines (28).

In the present study, novel lentiviral vectors were constructed for a CAR line consisting of an epidermal growth factor receptor variant III (EGFRvIII)-specific single chain variable fragment ( $\mathrm{scFv}$ ) coupled to the motifs of a $\mathrm{CD} 3 \zeta$ chain (T-cell receptor signaling module), and costimulatory CD137 (4-1BB) and CD28 (pELNS-3C10-CAR). The human NK cell line KHYG-1 was transduced with these lentiviral vectors and the EGFRvIII specific-CAR-KHYG-1 (EvCAR-KHYG-1) cell line was generated. The anti-tumor effects of this cell line were evaluated in vitro. This is the first study to establish a CAR NK line based on the human NK cell line KHYG-1.

\section{Materials and Methods}

Cell lines. Human GBM cell line U87MG and HEK293T cells were purchased from the American Type Culture Collection (ATCC; Manassas, VA, USA). EGFRvIII expressing-U87MG (U87MGEGFRvIII) cells were kindly provided by Atsushi Natsume of Nagoya University School of Medicine. GBM cells were maintained in Dulbecco's Modified Eagle Medium (DMEM; Thermo Fisher Scientific Inc., Waltham, MA, USA) supplemented with $10 \%$ heatinactivated fetal bovine serum (FBS; MP Biomedicals, Santa Ana, CA, USA). Human NK cell line KHYG-1 cells were purchased from Japanese Collection of Research Bioresources (JCRB; Ibaraki, Osaka, Japan) and maintained in Roswell Park Memorial Institute 1640 medium (RPMI 1640; Thermo Fisher Scientific Inc.) with 150 international units (IU)/ml of recombinant human Interleukin (rhIL)2 (Novartis Pharma AG, Basel, Switzerland) supplemented with $20 \%$ FBS. Each type of culture medium used in this study was supplemented with 100 units $/ \mathrm{ml}$ penicillin and $100 \mu \mathrm{g} / \mathrm{ml}$ streptomycin (Thermo Fisher Scientific Inc.). The cell lines were cultured under standard culture conditions at $37^{\circ} \mathrm{C}$ in a humidified atmosphere containing $5 \% \mathrm{CO}_{2}$.

Construction of self-inactivating (SIN) lentiviral vectors. The EGFRvIII-specific CAR carrying-self-inactivating (SIN) lentiviral vector was previously reported (31). mAb 3C10 was originally developed by immunization of mice with a 14-amino acid peptide incorporating an EGFRvIII-specific fusion junction (32), then its single chain variable fragment ( $\mathrm{scFv}$ ) was subsequently cloned (33). The $\mathrm{scFv}$ portion in pELNS-SS1CD28r1BBZeta was replaced with the cDNA for $3 \mathrm{C} 10 \mathrm{scFV}$ by gene synthesis (Genscript, Piscataway, $\mathrm{NJ})$ to create pELNS-3C10-CAR.

Production of vesicular stomatitis virus $G$ glycoprotein (VSV-G) pseudotype SIN-lentivirus and transduction of NK cells. Production of SIN-lentivirus was performed as previously described, with slight modifications (31). Briefly, HEK293T cells $\left(8 \times 10^{6}\right)$ were cultured in DMEM supplemented with $10 \%$ FBS in a $175-\mathrm{cm}^{2}$ flask (Corning, CA, USA) for $24 \mathrm{~h}$ under standard culture conditions. Next, the cells were co-transfected with EGFRvIII-specific CAR carrying SIN lentiviral vector together with the packaging vectors pMDLg/pRRE, pRSV-Rev and pMD2.G, kindly provided by Atsushi Natsume of Nagoya University School of Medicine, using calcium phosphate transfection reagent Fugene 6 (Promega Co., Madison, WI, USA), then incubated for $48 \mathrm{~h}$. The lentiviruscontaining culture supernatant was harvested and filtered using a $0.45-\mu \mathrm{m}$ filter unit (Millipore, Billerica, MA, USA) to remove cellular debris. Filtrated supernatant was mixed with PEG-it Virus Precipitation Solution (5x) (System Biosciences, Palo Alto, CA, USA) and incubated for $24 \mathrm{~h}$ at $4^{\circ} \mathrm{C}$. That mixture was then centrifuged at $1500 \times g$ for $30 \mathrm{mi}$ at $4^{\circ} \mathrm{C}$, and the pellet was resuspended in a volume $1 / 10$ of the original using cold sterile medium at $4{ }^{\circ} \mathrm{C}$ and stored at $-80^{\circ} \mathrm{C}$.

Lentivirus infection was performed as previously described (34). Briefly, $2 \times 10^{6} \mathrm{KHYG} 1$ cells were suspended in $2 \mathrm{ml}$ of lentiviral supernatant (MOI: 8 ) containing $8 \mu \mathrm{g} / \mathrm{ml}$ Polybrene (Sigma-Aldrich, St. Louis, MO, USA), 20\% FBS, and $450 \mathrm{IU} / \mathrm{ml} \mathrm{rhIL}-2$. Suspended cells were seeded into 6-well flat-bottomed culture plates (Corning). Cells were centrifuged at $2600 \mathrm{rpm}$ at room temperature for $45 \mathrm{~min}$, then the plates were placed in an incubator at $37^{\circ} \mathrm{C}$ for $2 \mathrm{~h}$. Infection was repeated on the same day and again the following day. Following the third transduction, cells were maintained in RPMI 1640 medium supplemented with $20 \% \mathrm{FBS}$ and $150 \mathrm{IU} / \mathrm{ml} \mathrm{rhIL}-2$ at $37^{\circ} \mathrm{C}$.

Detection and purification of CAR gene transduced-NK cells. Cells were stained with Biotin-SP-conjugated AffiniPure Goat AntiMouse IgG (Jackson Immuno Research Laboratories, West Grove, PA, USA) and Phycoerythrin (PE)-conjugated-Streptavidin (BD Biosciences, San Jose, CA, USA), then fixed with $1 \%$ paraformaldehyde/PBS at $4^{\circ} \mathrm{C}$ for more than $1 \mathrm{~h}$. Stained cells were then acquired using a BD FACSCalibur flow cytometer and analyzed with CellQuest software (BD Biosciences). The ratio of fluorescence intensity (RFI) was calculated as the mean fluorescent intensity obtained with the sample divided by the mean fluorescent intensity of the control.

CAR NK were enriched using Biotin-SP-conjugated AffiniPure Goat Anti-Mouse IgG and Dynabeads ${ }^{\circledR}$ Biotin Binder beads (Thermo Fisher Scientific Inc.), which are streptavidin conjugatedmagnetic beads, according to the manufacturer's instructions.

Growth inhibition assays. GBM cell lines were seeded into 24-well flat-bottomed culture plates (Corning) at $12 \times 10^{4}$ cells per well in $0.3 \mathrm{ml}$ of DMEM supplemented with $10 \%$ FBS. Following attachment of GBM cells to the plates, $0.1 \mathrm{ml}$ of NK cells was suspended in 10\% FBS containing DMEM and added at NK cellto-GBM cell (effector-to-target) ratios of $0: 1,1: 1$ and 5:1. The plates 


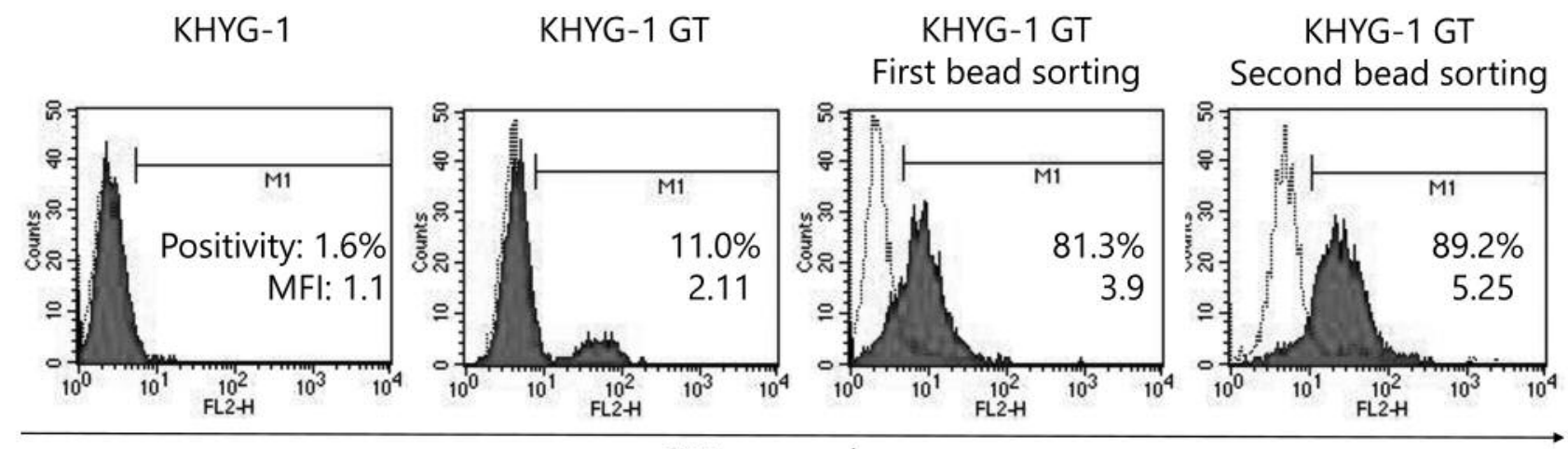

CAR expression

Figure 1. Establishment of EGFRvIII-specific CAR-expressing KHYG-1 cells. Initially, $11 \%$ of transduced CAR-KHYG-1 cells were positive for CAR expression on the cell surface (MFI: 2.11). Following a first round of magnetic bead sorting, EvCAR-expressing KHYG-1 cells were increased up to $81.3 \%$ (MFI: 3.90), then up to 89.2\% after the second round of sorting (MFI: 5.25). Open histograms indicate the isotype control and filled red histograms chimeric scFv (EGFRvIII) expression on NK-KHYG-1 cells.

were then incubated for $48 \mathrm{~h}$ at $37^{\circ} \mathrm{C}$ in a humidified atmosphere containing $5 \% \mathrm{CO}_{2}$. Following incubation, non-adherent cells were discarded, and adherent cells were trypsinized and stained with trypan blue dye. The number of viable non-stained cells was determined by manual counting.

Apoptosis detection. Apoptosis detection assays were performed using a MEBCYTO Apoptosis Kit (Medical and Biological Laboratories, Ltd., Nagoya, Aichi, Japan), according to the manufacturer's instructions. Briefly, GBM cells were exposed at effector-to-target ratios of $0: 1,1: 1$, and $5: 1$ for $24 \mathrm{~h}$ at $37^{\circ} \mathrm{C}$ in a humidified atmosphere containing $5 \% \quad \mathrm{CO}_{2}$. Non-adherent and trypsinized-adherent cells were washed with PBS and stained with annexin V-FITC at room temperature for $15 \mathrm{~min}$ in the dark. Stained cells were then analyzed using a FACSCalibur and CellQuest software. NK cells were excluded by electronic gating based on forward-scatter and side-scatter characteristics. The frequency of the annexin V-positive apoptotic cells is expressed as percentage of apoptotic cells among the total number of counted cells.

Statistical methods. Values are shown as the mean \pm standard error (SE). Statistical significance of differences was determined using a $t$-test or one-way analysis of variance (ANOVA), followed by Scheffe's test. Double asterisks indicate $p$-values $<0.01$.

\section{Results}

Establishment of human NK cell line KHYG-1 transduced with EGFRvIII-specific CAR. A lentiviral vector for CAR was generated that recognizes EGFRvIII through a singlechain variable fragment ( $\mathrm{scFv}$ ) derived from the human EGFRvIII-specific monoclonal antibody (mAb) 3C10 (pELNS-3C10-CAR). In this construct, the EF1 $\alpha$ promoter drives the CAR fusion protein integrating the 3C10-derived scFv, CD28 transmembrane (TM), and intracellular domains (ICDs), as well as the 4-1BB ICD and CD3 $\zeta$ domains.
EGFRvIII-specific CAR (EvCAR) were transduced into the NK cell line KHYG-1 and expression levels of the transgene were evaluated (Figure 1). Transduced-KHYG-1 showed $11 \%$ positivity for CAR expression on the cell surface (MFI: 2.11), indicating a low level of transduction efficacy (Figure 1, second panel from left). Since the proportion of EvCAR-positive cells was low, EvCARKHYG-1 cells were enriched using magnetic beads. Following the first round of magnetic bead sorting, EvCARexpressing KHYG-1 cells were increased by up to $81.3 \%$ (MFI: 3.90) (Figure 1, third panel from left), while that increase was up to $89.2 \%$ (MFI: 5.25) after the second round of magnetic sorting (Figure 1, first panel from right). The NK cells established in this manner were used in the following experiments.

EvCAR-KHYG-1 inhibits growth of EGFRvIII-expressing $U 87 M G$. To explore the growth inhibition effects of EvCARKHYG-1 on GBM in vitro, we performed co-cultures with the GBM cell lines U87MG and U87MG constitutively expressing EGFRvIII (U87-EGFRvIII) at a defined NK:GBM cell ratio for $72 \mathrm{~h}$. In co-cultures with EvCAR-KHYG-1, the ratios of NK to GBM cells were $0: 1,1: 1$, and 5:1. The viable cell numbers of U87MG cells were $47.1 \pm 3.1 \times 10^{4}$ (mean \pm SE), $48.6 \pm 1.9 \times 10^{4}$, and $56.4 \pm 2.8 \times 10^{4}$, respectively, and of U87MG-EGFRvIII cells were $37.4 \pm 2.3 \times 10^{4}, 36.2 \pm 2.1 \times 10^{4}$, and $13.8 \pm 2.6 \times 10^{4}$, respectively (Figure 2 ). On the other hand, in co-cultures with parental KHYG-1 and NK:GBM cell ratios of $0: 1,1: 1$, and $5: 1$, the viable cell numbers of U87MG cells were $41.7 \pm 6.9 \times 10^{4}, 50.7 \pm 3.1 \times 10^{4}$, and $50.4 \pm 4.2 \times 10^{4}$, respectively, and of U87MG-EGFRvIII cells were $41.1 \pm 4.4 \times 10^{4}, 47.0 \pm 3.7 \times 10^{4}$, and $43.8 \pm 3.4 \times 10^{4}$, respectively (Figure 2). These findings revealed that EvCAR-KHYG-1 
significantly inhibited U87MG-EGFRvIII growth at an NK:GBM cell ratio of 5:1 as compared to parental U87MG. Parental KHYG-1 showed no inhibition of the growth of U87MG or U87-EGFRvIII cells.

Constitutive EGFRvIII expression in U87MG cells enhances induction of apoptosis by EvCAR-KHYG-1. To investigate whether EvCAR-KHYG-1 induces tumor antigen-specific apoptosis, apoptosis detection assays with flow cytometry were used. At NK:GBM cell ratios of $0: 1,1: 1$, and 5:1, parental KHYG-1 induced apoptosis of U87MG cells by $2.9 \pm 0.6 \%, 19.5 \pm 1.1 \%$, and $31.0 \pm 0.8 \%$, respectively, while KHYG-1 induced U87MG-EGFRvIII cell apoptosis by $2.6 \pm 0.1 \%, \quad 14.1 \pm 0.5 \%$, and $29.7 \pm 1.3$, respectively. Furthermore, EvCAR-KHYG-1 induced apoptosis of U87MG cells by $2.9 \pm 0.5 \%, 18.0 \pm 0.9 \%, 35.5 \pm 0.9 \%$, respectively, and EvCAR-KHYG-1 strongly induced U87MG-EGFRvIII cell apoptosis by $2.6 \pm 0.1 \%, 34.2 \pm 1.4 \%$, and $78.2 \pm 1.6 \%$, respectively, at those NK:GBM cell ratios (Figures 3 and 4). Compared to parental KHYG-1, there was a significant increase in apoptosis of U87MG-EGFRvIII induced by EvCAR-KHYG-1.

\section{Discussion}

NK-92, a continuously growing human NK cell line, has been shown to be broadly cytotoxic against a spectrum of malignant cells (35-38), while other reports have noted that NK-92 cells prolonged survival of immunocompromised mouse models that underwent xenotransplantation with various types of human cancer $(37,38)$. On the other hand, there are few studies available regarding the human NK cell line NK-KHYG-1. This is the first report of CAR-KHYG-1 cells showing tumor-antigen specific cytotoxic effects towards EGFRvIII expressing GBM cell lines. CAR-KHYG1 cells were found to exhibit potent antigen-specific and cytotoxic activities towards U87 GBM cells stably expressing EGFRvIII.

For genetic engineering of primary CAR NK cells, viral vectors, such as retrovirus- and lentivirus-based vectors, have typically been applied, due to their stable integration into the genome. Lentiviral vectors have a moderate number of insertion mutations, though their lentiviral transduction efficiency is quite low (8-16\%) with PB-derived NK cells (28). The present findings also showed a low transduction rate $(11 \%)$, however following two rounds of enrichment of EvCAR-KHYG-1 cells with magnetic beads increased their presence to $89.2 \%$, indicating a good level of purification. CAR-engineered $\mathrm{T}$ cells targeting the B-cell differentiation antigen CD19 have demonstrated remarkable clinical efficacy in patients with lymphomas and leukemias of B-cell origin $(19,20)$. NK cells represent another important cell type for such adoptive immunotherapy, though CAR-

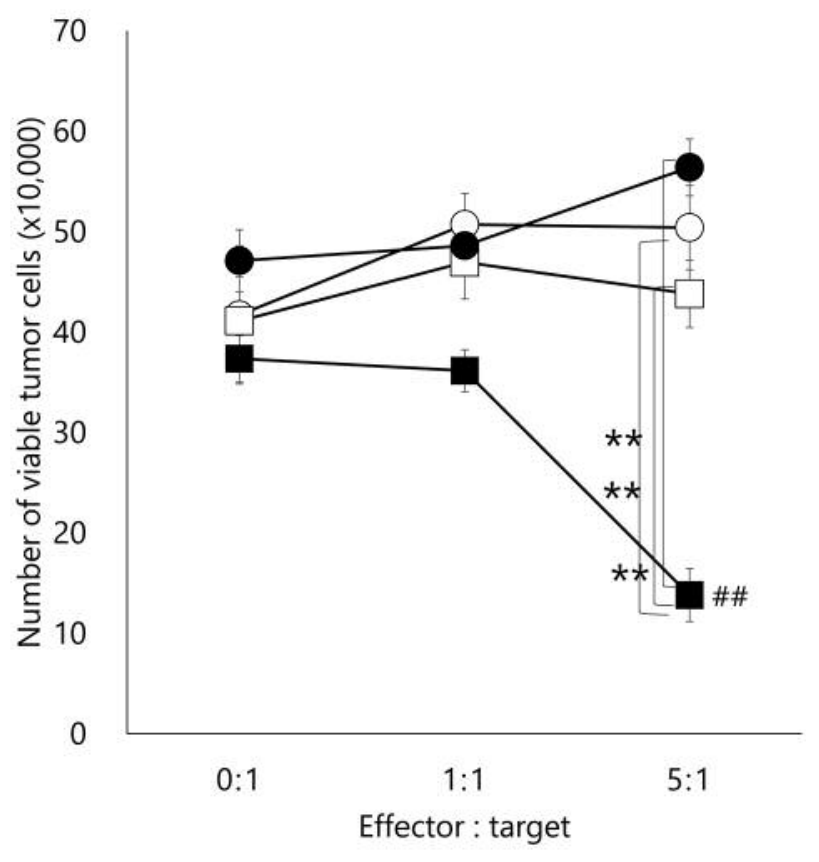

- -U87MG/KHYG-1

--U87MG-EGFRvIII/KHYG-1

U87MG/ $\alpha$ EGFRvIII-CAR-KHYG-1

U87MG-EGFRvIII/ $\alpha$ EGFRvIII-CAR-KHYG-1

$\# \#,{ }^{* *} P<0.01$

Figure 2. Growth inhibition assay findings. An E:T ratio of 5:1 resulted in significant suppression of the increase in the number of viable cell targets, U87MG or U87MG-EGFRvIII. (\#\#, **p<0.01; $n=4)$.

mediated retargeting of NK cells has not been frequently attempted. Currently, only a few clinical trials using CARtransduced NK cells, including CAR-modified NK-92 and primary NK cells, are in progress $(28,39)$.

Despite the early success of CAR T therapy, particularly as treatment for hematological malignancies, large-scale clinical application of CAR T therapy may be limited by individualized preparation methods and various potential side effects $(28,40)$. Furthermore, CAR T therapy can result in cytokine storms (30) and may induce graft-versus-host disease (GVHD) in an allogeneic transplantation setting (29).

NK cells have been proposed to be superior as CAR drivers for T cells (27) and shown to have several advantages when used in CAR-based immunotherapy as compared to $\mathrm{T}$ cells $(28,41,42)$. EvCAR-KHYG-1 has the ability to 


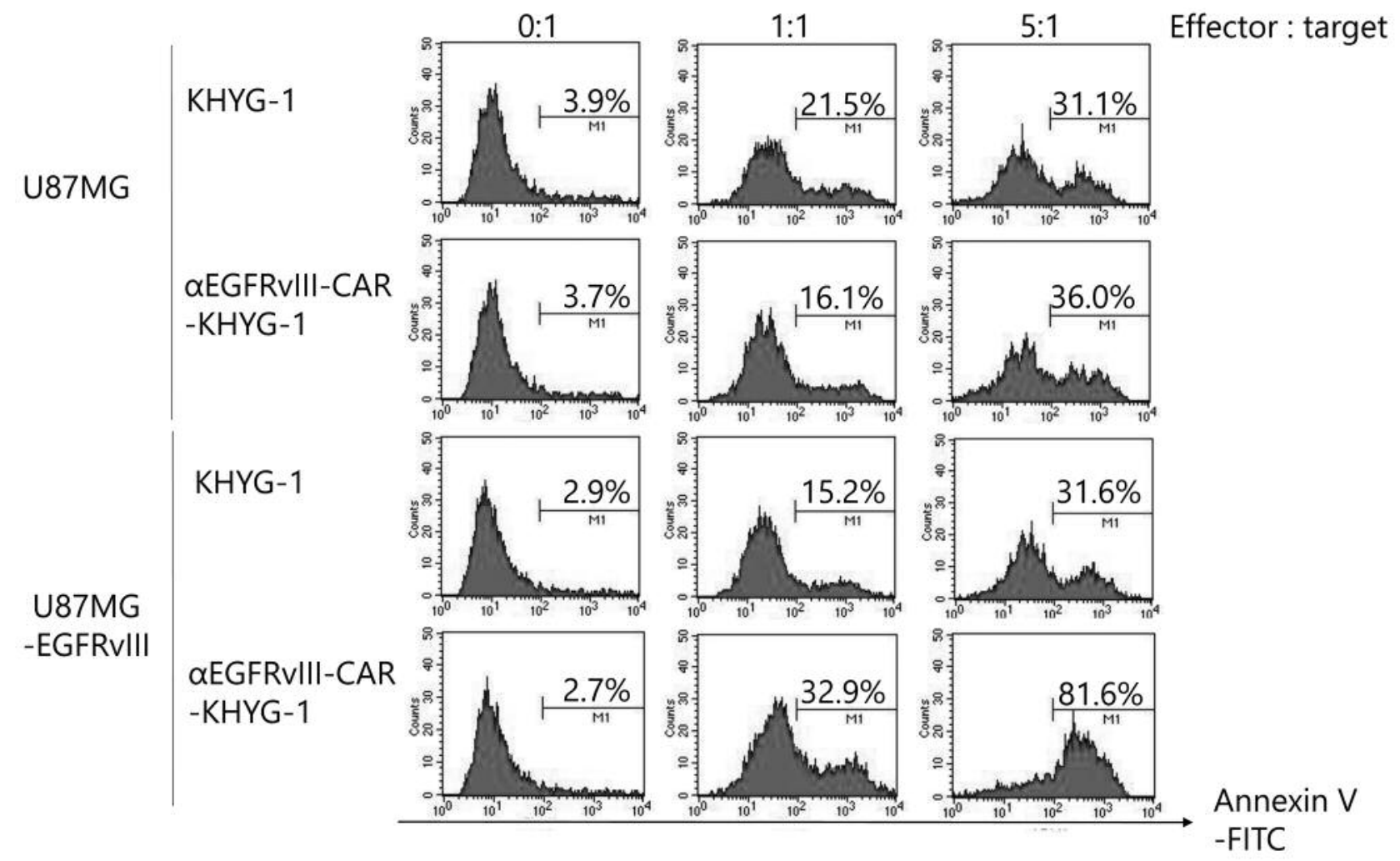

Figure 3. Representative findings of apoptosis detection assays. EvCAR-KHYG-1 at NK:GBM cell ratios of 0:1, 1:1, and 5:1 strongly induced U87MG-EGFRvIII apoptosis by $2.6 \pm 0.1 \%, 34.2 \pm 1.4 \%$, and $78.2 \pm 1.6 \%$, respectively.

suppress an increasing number of target cells in a tumor antigen specific manner, as indicated by the present tumor growth inhibition assay findings (Figure 3). Moreover, apoptosis detection assay results showed that EvCARKHYG-1 significantly increased EFGRvIII tumor antigenspecific apoptosis.

CARs offer several advantages as compared with traditional T-cell receptor (TCR)-mediated targeting of tumor antigens. Unlike TCRs, CARs do not require antigen presentation by the major histocompatibility complex (MHC), which is often down-regulated in gliomas $(43,44)$. Use of CARs has evolved over the recent decade, with progressively increasing co-stimulatory activity gained (16, 45). In addition to a single signaling unit derived from the $\mathrm{CD} 3 \zeta$ chain, the second generation of CARs incorporates the intracellular domain of CD28, a co-stimulatory molecule, or the tumor necrosis factor (TNF) receptor family member CD137 (4-1BB). Incorporation of both CD28 and CD137 has been shown to enhance the ability of these receptors to stimulate cytokine secretion and, hence, the antitumor efficacy of third generation CARs $(4,31)$. In general, second generation CARs in NK cells are more active than the first generation (28). The important co-stimulatory molecule 4-1$\mathrm{BB}$ is combined with $\mathrm{CD} 3 \zeta$ as an intracellular domain, which significantly enhances the targeted lysis of CAR-NK cells $(28,46-48)$.

EGFRvIII expression has been reported in a variety of tumor types, including GBM, while it is rarely observed in normal tissues $(11,12,49-55)$. Another report noted that it was expressed in $24 \%$ to $67 \%$ of GBM cases and that expression was found to be an independent negative prognostic indicator in patients surviving $\geq 1$ year (56). As an off-the-shelf therapeutic modality, continuously expanding CAR-KHYG-1 cells may show clinical usefulness for treatment of cancer patients, particularly in cases where the infrastructure or suitable donors for a CAR $\mathrm{T}$ approach are not readily available. Even at low E/T ratios, EvCARKHYG-1 cells displayed more pronounced cell killing than KHYG-1 cells. That may contribute to both direct and indirect antitumor effects, and should be considered as part of further development of this approach for clinical applications.

In summary, the EvCAR-KHYG-1 cell line was established by self-inactivated lentivirus-based transduction 


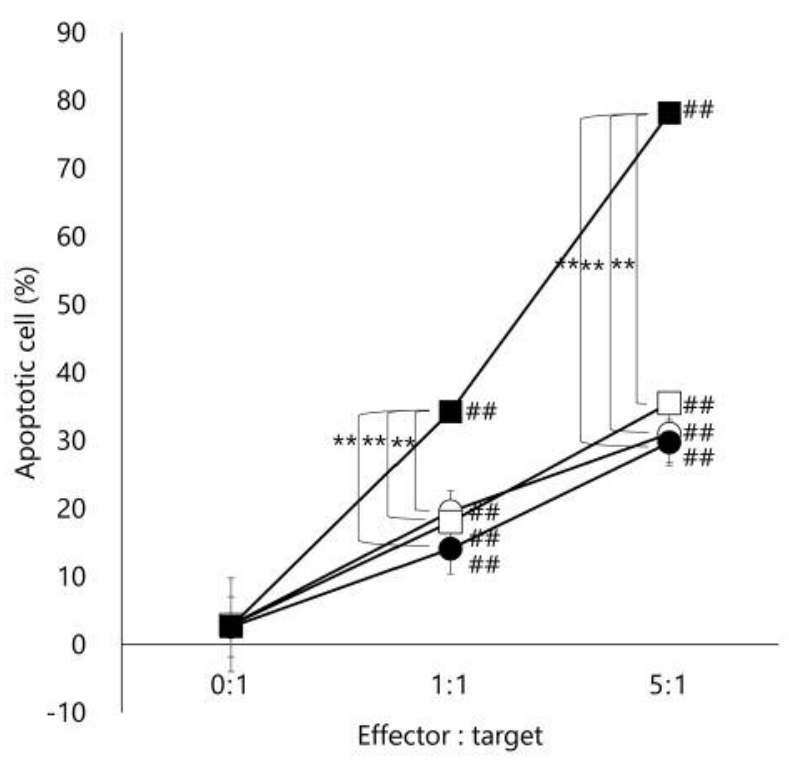

- -U87MG/KHYG-1

-ㅁ-U87MG/ $\alpha$ EGFRvIII-CAR-KHYG-1

-U87MG-EGFRvIII/KHYG-1

-U87MG-EGFRvIII/ $\alpha$ EGFRvIII-CAR-KHYG-1

$\# \#,{ }^{\star \star} P<0.01$

Figure 4. Apoptosis of targets induced by parental KHYG-1 cells was generally $<13 \%$ at an E:T ratio of $1: 1$ and $<30 \%$ at a 5:1 ratio. In contrast, apoptosis induced by EvCAR-KHYG was significantly greater, up to $31-37 \%$ at an E:T ratio of $1: 1$ and $75-81 \%$ at a ratio of 5:1. (\#\#, $* * p<0.01 ; n=3)$.

of the EvCAR gene and magnetic bead-based purification of EvCAR-expressing NK cells. The EvCAR-KHYG-1 cell line inhibited GBM cell growth via apoptosis in an EGFRvIIIexpressing specific manner. Thus, EvCAR-KHYG-1 may become an effective treatment option for patients with GBM.

\section{Conflicts of Interest}

None of the Authors have conflicts of interest to declare in regard to this study.

\section{Acknowledgements}

This study was supported by a Grant-in-aid for Scientific Research (No. 16K10767) from the Japan Society for the Promotion of Science.

\section{References}

1 Stupp R, Hegi ME, Mason WP, van den Bent MJ, Taphoorn MJB, Janzer RC, Ludwin AK, Allgeier A, Fisher B, Belanger K, Hau P, Brandes AA, Gijtenbeek J, Marosi C, Vecht CJ, Mokhtari K, Wesseling P, Villa S, Eisenhauer E, Gorlia T, Weller M, Lacombe D, Cairncross JG and Mirimanoff RO: Effects of radiotherapy with concomitant and adjuvant temozolomide versus radiotherapy alone on survival in glioblastoma in a randomized phase III study: 5-year analysis of the EORTCNCIC trial. Lancet Oncol 10: 459-466, 2009.

2 Stupp R, Mason WP, van den Bent MJ, Weller M, Fisher B, Taphoorn MJB, Belanger K, Brandes AA, Marosi C, Bogdahn U, Curschmann J, Janzer RC, Ludwin SK, Gorlia T, Allgeier A, Lacombe D, Cairncross JG, Eisenhauer E and Mirimanoff RO: Radiotherapy plus concomitantand adjuvant temozolomide for glioblastoma. N Engl J Med 352: 987-986, 2005.

3 Gilbert MR, Dignam JJ, Armstrong TS, Wefel JS, Blumenthal DT, Vogelbaum MA, Colman H, Chakravarti A, Pugh S, Won M, Jeraj R, Brown PD, Jaeckle KA, Schiff D, Stieber VW, Brachman DG, Werner-Wasik M, Tremont-Lukats IW, Sulman EP, Aldape KD, Curran WJ and Mehta MP: A randomized trial of bevacizumab for newly diagnosed glioblastoma. N Engl J Med 370: 699-708, 2014.

4 Shiina S, Ohno M, Ohka F, Kuramitsu S, Yamamichi A, Kato A, Motomura K, Tanahashi K, Yamamoto T, Watanabe R, Ito I, Senga T, Hamaguchi M, Wakabayashi T, Kaneko MK, Kato Y, Chandramohan V, Bigner DD and Natsume A: CAR T cells targeting podoplanin reduce orthotopic glioblastomas in mouse brains. Cancer Immunol Res 4: 259-268, 2016.

5 Riccione K, Suryadevara CM, Snyder D, Cui X, Sampson JH and Sanchez-Perez L: Generation of CAR T cells for adoptive therapy in the context of glioblastomas standard of care. J Vis Exp 96: e52397, 2015.

6 Nakazawa T, Nakamura M, Matsuda R, Nishimura F, Park YS, Motoyama Y, Hironaka Y, Nakagawa I, Yokota H, Yamada S, Tamura K, Takeshima Y, Omoto K, Tanaka Y, Ouji Y, Yoshikawa M, Tsujimura T and Nakase H: Antitumor effects of minodronate, a third-generation nitrogen-containing bisphosphonate, in synergy with $\gamma \delta \mathrm{T}$ cells in human glioblastoma in vitro and in vivo. $\mathrm{J}$ Neurooncol 129: 231-241, 2016.

7 Nakazawa T, Nakamura M, Park YS, Motoyama Y, Hironaka Y, Nishimura F, Nakagawa I, Yamada S, Matsuda R, Tamura K, Sugimoto T, Takeshima Y, Marutani A, Tsujimura T, Ouji N, Ouji Y, Yoshikawa $\mathrm{M}$ and Nakase $\mathrm{H}$ : Cytotoxic human peripheral blood-derived $\gamma \delta$ T cells kill glioblastoma cell lines: implications for cell-based immunetherapy for patients with glioblastoma. J Neurooncol 116: 31-39, 2014.

8 Vauleon E, Avril T, Collet B, Mosser J and Quillien V: Overview of cellular immunotherapy for patients with glioblastoma. Clin Dev Immunol 2010: 689171, 2010.

9 Johnson LA and Sampson JH: Immunotherapy approaches for malignant glioma from 2007 to 2009. Curr Neurol Neurosci Rep 10: 259-266, 2010.

10 Ahmed N, Salsman VS, Kew Y, Shaffer D, Powell S, Zhang YJ, Grossman RG, Heslop HE and Gottschalk S: HER2-specific T cells target primary glioblastoma stem cells and induce regression of autologous experimental tumors. Clin Cancer Res 16: 474-485, 2010. 
11 O’Rourke DM, Nasrallah MP, Desai A, Melenhorst JJ, Mansfield K, Morrissette JJD, Martinez-Lage M, Brem S, Maloney E, Shen A, Isaacs R, Mohan S, Plesa G, Lacey SF, Navenot JM, Zheng Z, Levine BL, Okada H, June CH, Brogdon JL and Maus MV: A single dose of peripherally infused EGFRvIII-directed CAR T cells mediates angiten loss and induces adaptive resistance in patients with recurrent glioblastoma. Sci Transl Med 9: eaaa0984, 2017.

12 Gen $\beta$ ler S, Burger MC, Zhang C, Oelsner S, Mildenberger I, Wagner M, SteinBach JP and Wels WS: Dual targeting of glioblastoma with chimeric antigen receptor-engineered natural killer cells overcomes heterogeneity of target antigen expression and enhances antitumor activity and survival. Oncoimmunology 5(4): e1119354, 2016.

13 Ogbomo H, Cinatl J Jr., Mody $\mathrm{CH}$ and Forsyth PA: Immunotherapy in gliomas: limitations and potential of natural killer (NK) cell therapy. Trends Mol Med 17: 433-441, 2011.

14 Zhang C, Oberoi P, Oelsner S, Waldmann A, Lindner A, Tonn T and Wels WS: Chimeric antigen receptor-engineered NK-92 cells: an off-the-shelf cellular therapeutic for targeted elimination of cancer cells and induction of protective antitumor immunity. Front. Immunol 8: 533, 2017.

15 Oelsner S, Friede ME, Zhang C, Wagner J, Badura S, Bader P, Ullrich E, Ottmann OG, Klingemann H, Tonn T and Wels WS: Continuously expanding CAR NK-92 cells display selective cytotoxicity against B-cell leukemia and lymphoma. J Cell Ther 19: 235-249, 2017.

16 Sadelain M, Brentjens R and Riviere I: . The basic principles of chimeric antigen receptor design. Cancer Discov 3: 388-398, 2013.

17 Sadelain M, Riviere I and Brentjens R: Targeting tumors with genetically enhanced T lymphocytes. Nat Rev Cancer 3: 35-45, 2003

18 Ho WY, Blattman JN, Dossett ML, Yee C and Greenberg PD: Adoptive immunotherapy: engineering $\mathrm{T}$ cell responses as biologic weapons for tumor mass destruction. Cancer cell 3: 431-437, 2003.

19 Kochenderfer JN, Dudley ME, Feldman SA, Wilson WH, Spaner DE, Maric I, Stetler-Stevenson M, Phan GQ, Hughes MS, Sherry RM, Yang JC, Kammula US, Devillier L, Carpenter R, Nathan DN, Morgan RA, Laurencot C and Rosenberg SA: B-cell depletion and remissions of malignancy along with cytokineassociated toxicity in a clinical trial of anti-CD19 chimericantigen-receptor-transduced T cells. Blood 119(12): 2709-2720, 2012.

20 Porter DL, Levine BL, Kalos M, Bagg A and June CH: Chimeric antigen receptor- modified $\mathrm{T}$ cells in chronic lymphoid leukemia. N Engl J Med 365: 725-733, 2011.

21 Maude SL, Teachey DT, Porter Dl and Grupp SA: CD19targeted chimeric antigen receptor T-cell therapy for acute lymphoblastic leukemia. Blood 125: 4017-4023, 2015.

22 Ahmed N, Brawley VS, Hegde M, Robertson C, Ghazi A, Gerken C, Liu E, Dakhova O, Ashoori A, Corder A, Gray T, Dotti G, Mei Z, Grilley B, Gee A, Rooney CM, Brenner MK, Heslop HE and Gottschalk S: Human epidermal growth factor receptor 2 (HER2)-specific chimeric antigen receptor-modified $\mathrm{T}$ cells for the immunotherapy of HER2-positive sarcoma. J Clin Oncol 33: 1688-1696, 2015

23 Katz SC, Burga RA, McCormack E, Wang LJ, Mooring W, Point GR, Khare PD, Thorn M, Ma Q, Stainken BF, Assanah EO,
Davies R, Espat NJ and Junghans RP: Phase I hepatic immunotherapy for metastases study of intraarterial chimeric antigen receptor-modified T-cell therapy for CEA+ liver metastases. Clin Cancer Res 21: 3149-3159, 2015.

24 Feng K, Guo Y, Dai H, Wang Y, Li X, Jia H and Han W: Chimeric antigen receptor-modified $\mathrm{T}$ cells for the immunotherapy of patients with EGFR-expressing advanced relapsed/refractory non-small cell lung cancer. Sci China Life Sci 59: 468-479, 2016.

25 Uherek C, Tonn T, Uherek B, Becker S, Schnierle B, Klingemann HG and Wels W: Retargeting of natural killer-cell cytolytic activity to ErbB2-expressing cancer cells results in efficient and selective tumor cell destruction. Blood 100: 1265-1273, 2002.

26 Imai C, Iwamoto S and Campana D: Genetic modification of primary natural killer cells overcomes inhibitory signals and induces specific killing of leukemic cells. Blood 106: 376-383, 2005.

27 Klingemann H.: Are natural killer cells superior CAR drivers? OncoImmunology 3: e28147-1-4, 2014.

$28 \mathrm{Hu} \mathrm{Y,} \mathrm{Tian} \mathrm{Z}$ and Zhang C: Chimeric antigen receptor (CAR)transduced natural killer cells in tumor immunotherapy. Acta Pharmacologica Sin 39: 167-176, 2018.

29 Maus MV: Designing CAR $\mathrm{T}$ cells for glioblastoma. Oncoimmunology 4: 12, e1048956, 2015.

30 Morgan RA, Yang JC, Kitano M, Dudley ME, Laurencot CM and Rosenberg SA: Case report of a serious adverse event following the administration of $\mathrm{T}$ cells transduced with a chimeric antigen receptor recognizing ERBB2. Mol Ther 18(4): 843-851, 2010

31 Ohno M, Ohkuri T, Kosaka A, Tanahashi K, June CH, Natsume A and Okada H: Expression of miR-17-92 enhances anti-tumor activity of T-cells transduced with the anti-EGFRvIII chimeric antigen receptor in mice bearing human GBM xenografts. J Immunother Cancer 1: 21, 2013.

32 Okamoto S. Yoshikawa K, Obata Y, Shibuya M, Aoki S, Yoshida $\mathrm{J}$ and Takahashi T: Monoclonal antibody against the fusion junction of a deletion-mutant epidermal growth factor receptor. Br J Cancer 73: 1366-1372, 1996.

33 Nakayashiki N, Yoshikawa K, Nakamura K, Hanai N, Okamoto K, Okamoto S, Mizuno M, Wakabayashi T, Saga S, Yoshida J and Takahashi T: Production of a single-chain variable fragment antibody recognizing type III mutant epidermal growth factor receptor. JPN J Cancer Res 91: 1035-1043, 2000.

34 Chu J, Deng Y, Benson DM Jr., He S, Hughes T, Zhang J, Peng Y, Mao H, Yi L, Ghoshal K, He X, Devine SM, Zhang X, Caligiuri MA, Hofmeister CC and Yu J: CS1-specific chimeric antigen receptor (CAR)-engineered natural killer cells enhance in vitro and in vivo antitumor activity against human multiple myeloma. Leukemia 28: 917-927, 2014.

35 Romanski A, Uherek C, Bug G, Seifried E, Kingemann H, Wels WS, Ottmann OG and Tonn T: CD19-CAR engineered NK-92 cells are sufficient to overcome NK cell resistance in B-cell malignancies. J Cell Mol Med 20: 1287-1294, 2017.

36 Klingemann HG, Wong E and Maki G: A cytotoxic NK-cell line (NK-92) for ex vivo purging of leukemia from blood. Biol Blood Marrow Transplant 2: 68-75, 1996.

37 Tam YK, Miyagawa B, Ho VC and Klingemann HG: Immunotherapy of malignant melanoma in a SCID mouse model using the highly cytotoxic natural killer cell line NK-92. J Hematother 8: 281-290, 1999. 
38 Yan Y, Steinherz P, Klingemann HG, Dennig D, Childs BH, McGuirk J and O'Reilly RJ: Antileukemia activity of a natural killer cell line against human leukemias. Clin Cancer Res 4: 2859-2868, 1998

39 Williams BA, Law AD, Routy B, denHollander N, Gupta V, Wang XH, Chaboureau A, Viswanthan S and Keating A: A phase I trial of NK-92 cells for refractory hematological malignancies relapsing after autologous hematological malignancies relapsing after autologous hematopoietic cell transplantation shows safety and evidence of efficacy. Oncotarget 8(51): 89256-89268, 2017.

40 Brown CE, Alizadeh D, Starr R, Weng L, Wagner JR, Naranjo A, Ostberg JR, Blanchard MS, Kilpatrick J, Simpson J, Kurien A, Priceman SJ, Wang X, Harshbarger TL, D’Apuzzo M, Ressler JA, Jensen MC, Barish ME, Chen M, Portnow J, Forman SJ and Badie B: Regression of glioblastoma after chimeric antigen receptor T-cell therapy. N Engl J Med 375: 2561-2569, 2016.

41 Han J, Chu J, Chan WK, Zhang J, Wang Y, Cohen JB, Victor A, Meisen WH, Kim SH, Grandi P, Wang QE, He X, Nakano I, Chiocca EA, Glorioso JC 3rd, Kaur B, Caligiuri MA and Yu J: CAR-engineered NK cells Targeting Wild-Type EGFR and EGFRvIII enhance killing of glioblastoma and patient-derived glioblastoma stem cells. Sci Rep 5: 11483, 2015.

42 Müller N, Michen S, Tietze S, Töpfer K, Schulte A, Lamszus K, Schmitz M, Schackert G, Pastan I and Temme A: Engineering NK cells modified with an EGFRvIII-specific chimeric antigen receptor to overexpress CXCR4 improves immunotherapy of CXCL12/SDF-1 $\alpha$-secreting glioblastoma. J Immunother 38(5): 197-210, 2015.

43 Facoetti A, Nano R, Zelini P, Morbini P, Benericetti E, Ceroni M, Campoli M and Ferrone S: Human leukocyte antigen and antigen processing machinery component defects in astrocytic tumors. Clin Cancer Res 11: 8304-8311, 2005.

44 Yeung JT, Hamilton RL, Ohnishi K, Ikeura M, Potter DM, Nikiforova MN, Ferrone S, Jakacki RI, Pollack IF and Okada H: $\mathrm{LOH}$ in the HLA class I region at $6 \mathrm{p} 21$ is associated with shorter survival in newly diagnosed adult glioblastoma. Clin Cancer Res 19(7): 1816-1826, 2013.

45 Kobayashi E, Kishi H, Ozawa T, Hamana H, Nakagawa H, Jin A, Lin Z and Muraguchi A: A chimeric antigen receptor for TRAIL-receptor 1 induces apoptosis in various types of tumor cells. Biochem and Biophys Res Commun 453: 798-803, 2014.

46 Hermanson DL and Kaufman DS: Utilizing chimeric antigen receptors to direct natural killer cell activity. Front Immunol 6: 195, 2015.

47 Wang R, Freywald A, Chen Y, Xu J, Tan X and Xiang J: Transgenic 4-1BBL-engineered vaccine stimulates potent Gagspecific therapeutic and long-term immunity via increased priming of CD44+CD62L(high) IL-7R+ CTLs with up- and downregulation of anti- and pro-apoptosis genes. Cell Mol Immunol 12: 456-465, 2015.

48 Rahman K and Iyer SS: Costimulatory molecules as vaccine adjuvants: to $4-1 \mathrm{BB}$ or not to $4-1 \mathrm{BB}$ ? Cell Mol Immunol 12: 508-509, 2015.
49 Choi B, Suryadevara CM, Gedeon PC, Herndon JE 2nd, Sanchez-Perez L, Bigner DD and Sampson JH: Intracerebral delivery of a third generation EGFRvIII-specific chimeric antigen receptor is efficacious against human glioma. J Clin Neurosci 21: 189-190, 2014.

50 Johnson LA, Scholler J, Ohkuri T, Kosaka A, Patel PR, McGettigan SE, Nace AK, Dentchev T, Thekkat P, Loew A, Boesteanu AC, Cogdill AP, Chen T, Fraietta JA, Kloss CC, Posey AD Jr., Engels B, Singh R, Ezell T, Idamakanti N, Ramones MH, Li N, Zhou L, Plesa G, Seykora JT, Okada H, June CH, Brogdon $\mathrm{JL}$ and Maus MV: Rational development and characterization of humanized anti-EGFR variant III chimeric antigen receptor T cells for glioblastoma. Sci Transl Med 7(275): 275ra22, 2015.

51 Ruella M and Levine BL: Smart CARS: optimized development of a chimeric antigen receptor (CAR) $\mathrm{T}$ cell targeting epidermal growth factor receptor variant III (EGFRvIII) for glioblastoma. Ann Transl Med 4: 13, 2016.

52 Miao H, Choi BD, Suryadevara CM, Sanchez-Perez L, Yang S, De Leon G, Sayour EJ, McLendon R, Herndon JE 2nd, Healy P, Archer GE, Bigner DD, Johnson LA and Sampson JH: EGFRvIIIspecific chimeric antigen receptor $\mathrm{T}$ cells migrate to and kill tumor deposits infiltrating the brain parenchyma in an invasive xenograft model of glioblastoma. PLoS ONE 9(4): e94281, 2014.

53 Kuramitsu S, Ohno M, Ohka F, Shiina S, Yamamichi A, Kato A, Tanahashi K, Motomura K, Kondo G, Kurimoto M, Senga T, Wakabayashi $\mathrm{T}$ and Natsume A: Lenalidomide enhances the function of chimeric antigen receptor $\mathrm{T}$ cells against the epidermal growth factor receptor variant III by enhancing immune synapses. Cancer Gene Therapy 22: 487-495, 2015.

54 Sampson JH, Choi BD, Sanchez-Perez L, Suryadevara CM, Snyder DJ, Flores CT, Schmittling RJ, Nair SK, Reap EA, Norberg PK, Herndon JE 2nd, Kuan CT, Morgan RA, Rosenberg SA and Johnson LA: EGFRvIII mCAR-modified T-cell therapy cures mice with established intracerebral glioma and generates host immunity against tumor-antigen loss. Clin. Cancer Res 20(4): 972-984, 2014

55 Wikstrand CJ, Hale LP, Batra SK, Hill ML, Humphrey PA, Kurpad SN, McLendon RE, Moscatello D, Pegram CN, Reist CJ, Traweek ST, Wong AJ, Zalutsky MR and Bigner DD: Monoclonal antibodies against EGFRvIII are tumor specific and react with breast and lung carcinomas and malignant gliomas. Cancer Res 55: 3140-3148, 1995.

56 Ohno M, Natsume A, Iwaimi K, Iwamizu H, Noritake K, Ito D, Toi Y, Ito M, Motomura K, Yoshida J, Yoshikawa $\mathrm{K}$ and Wakabayashi T: Retrovirally engineered T-cell based immunotherapy targeting type III variant epidermal growth factor receptor, a glioma-associated antigen. Cancer Sci 101: 2518-2524, 2010. 